UDC 330.15

Submitted: 28.08 .2020

LBC 65.04, 65.050

Accepted: 02.10 .2020

\title{
FINANCIAL SUPPORT FOR GREEN ECONOMY PROJECTS IN RUSSIA BASED ON THE PRINCIPLES OF SUSTAINABLE DEVELOPMENT ${ }^{1}$
}

\author{
Andrey A. Anikin \\ Volgograd State University, Volgograd, Russian Federation
}

\begin{abstract}
The article presents the results of the analysis of the Russian eco-finance system: fundamental strategies, key regulatory documents, measures and tools. The analysis was based on the methodology of sustainable development and consideration of ESG factors. We found that the formation of the institutional framework of ecofinance and the development of advanced measures of support and stimulation of projects of green economy takes into account methodological principles for sustainable development: integrating anthropogenic impacts on natural areas; balanced decision-making on establishing regulatory requirements in the field of environmental safety, responsibility for negative impact on the environment; priority of national interests in the development of measures. The analysis showed that there is an established system of measures to support and stimulate eco-projects, both administrative and financial, direct and indirect, incentives and sanctions. The system is evolving and being modernized: measures have been developed and implemented to support issuers of securities whose target orientation (securities) is related to investing in eco-projects, and a draft article "Environmental tax" has been developed and is being discussed. The features of the Russian system of support and stimulation of environmental projects are its "youth", being at the stage of formation, and the "lack of configuration" of economic mechanisms, which makes it difficult to assess the effectiveness of the measures taken. When evaluating environmental projects and the effectiveness of support measures, it is advisable to take into account the principles of sustainable economy, as well as the relationship and mutual influence of ESG factors.

Key words: sustainable growth, green economy, financial incentives and support for environmental projects, regional economy, economy.

Citation. Anikin A.A. Financial Support for Green Economy Projects in Russia Based on the Principles of Sustainable Development. Journal of Volgograd State University. Economics, 2020, vol. 22, no. 3, pp. 148-159. (in Russian). DOI: https://doi.org/10.15688/ek.jvolsu.2020.3.13
\end{abstract}

УДК 330.15

ББК $65.04,65.050$

Дата поступления статьи: 28.08.2020

Дата принятия статьи: 02.10.2020

\section{ФИНАНСОВАЯ ПОДДЕРЖКА ПРОЕКТОВ ЗЕЛЕНОЙ ЭКОНОМИКИ В РОССИИ НА ОСНОВЕ ПРИНЦИПОВ УСТОЙЧИВОГО РАЗВИТИЯ ${ }^{1}$}

\author{
Андрей Андреевич Аникин \\ Волгоградский государственный университет, г. Волгоград, Российская Федерация
}

\begin{abstract}
Аннотация. В статье представлены результаты исследования российской системы экофинансирования: основополагающих стратегий, ключевых нормативных документов, мер и инструментов. Анализ опирался на методологию устойчивого развития и учет ESG-факторов. Выявлено, что при формировании институционального каркаса экофинансов и разработке современных мер поддержки и стимулирования проектов зеленой экономики учитываются методологические принципы устойчивого развития: комплексный учет воздействия антропогенных факторов на все природные сферы; взвешенность в принятии решений по установлению нормативных требований в сфере экологической безопасности, ответственность за негативное воздействие на окружающую среду; приоритет национальных интересов при разработке мер. Анализ показал наличие сложившейся системы мер поддержки и стимулирования экопроектов как административных, так и финансовых, прямых и косвенных, стимулирующих и санкционных. Система эволюционирует и модернизируется: разрабо() таны и реализуются меры поддержки эмитентов ценных бумаг, целевая направленность которых (ценных бу-
\end{abstract}


маг) связана с инвестированием в экопроекты, разработан и проходит стадию обсуждения проект внесения в Налоговый кодекс Российской Федерации статьи «Экологический налог». Особенностями российской системы поддержки и стимулирования экологических проектов является ее «молодость», нахождение в стадии становления, «ненастроенность» экономических механизмов, что приводит к сложности оценки эффективности принимаемых мер. При оценке экологических проектов и эффективности мер их поддержки целесообразно учитывать принципы устойчивой экономики, а также взаимосвязь и взаимовлияние ESG-факторов.

Ключевые слова: устойчивый рост, «зеленая экономика», финансовое стимулирование и поддержка экологических проектов, региональная экономика, экономика.

Цитирование. Аникин А. А. Финансовая поддержка проектов зеленой экономики в России на основе принципов устойчивого развития // Вестник Волгоградского государственного университета. Экономика. 2020. - T. 22, № 3. - C. 148-159. - DOI: https://doi.org/10.15688/ek.jvolsu.2020.3.13

\section{Введение}

Современная финансовая система все больше ориентируется на соблюдение глобальных принципов устойчивого экономического развития в своей деятельности. Факторами зеленой финансовой системы являются экологические, экономические и социальные факторы (далее - ESG-факторы). Мировая практика накопила к настоящему времени достаточную институциональную базу в сфере экофинансов, опыт применения которой необходимо адаптировать к российской практике. В России разработаны стратегические документы, формирующие систему зеленой экономики и ее финансирования, которые в 2018 и 2019 гг. стали прорывными с точки зрения как разработки методологических материалов по данной проблематике, так и их внедрения на практике. Это свидетельствует об актуальности экологической проблематики в российской экономике и необходимости дальнейших исследований в данной области.

В процессе исследования применялись общенаучные методы, процессный и системный подходы к изучаемым проблемам. Научную основу статьи составили труды ученых по проблемам финансирования экопроектов в российской экономике, среди которых: О. Богачева и О. Смородинов [Богачева и др., 2016], Е. Каменева [Каменева и др., 2015], Е. Тютюкина [Тютюкина и др., 2015], Т. Седаш [Cедаш, 2017], М. Гутборг, Ю. Храплива, С. Володин [Гутборг и др., 2017]. Анализом налогового инструментария стимулирования зеленых проектов в российской экономике занимаются такие исследователи, как И. Горкина и Т. Филичева [Филичева и др., 2018].
Для оценки эффективности мер поддержки и стимулирования экологических проектов целесообразно принимать во внимание ESG-факторы. В исследовании проведен анализ динамики показателей, характеризующих ESG-факторы: объемы сброса сточных вод и выбросов загрязняющих веществ в атмосферу, количество экологических преступлений, платежи за негативное воздействие на окружающую среду, инвестиции в основной капитал, направленные на охрану окружающей среды.

Меры государственной поддержки зеленой экономики и рынка зеленого финансирования можно классифицировать по следующим группам: по форме участия (прямое и косвенное); по видам поддержки (административные и финансовые); по направлениям поддержки (стимулирующие, санкционные).

Среди административных мер выделим следующие: 1) институциональные: формирование «контура поддержки» рынка зеленого финансирования (разработка и реализация стратегий, концепций, законодательных актов, формирующих, контролирующих, стимулирующих, регулирующих развитие зеленой экономики и зеленого финансирования); 2) организационные: организация, финансирование, стимулирование научно-исследовательской и аналитической работы по тематике зеленой экономики и финансов; снижение рисков посредством разработки соответствующих методических документов о классификации и оценке рисков.

Меры финансовой поддержки зеленой экономики: 1) прямые: стратегические выпуски облигаций с целью развития рынка, поддержания его ликвидности (выпуск суверенных и муниципальных облигаций, банковских облигаций); прямое государственное участие на этапах проектирования и подготовки про- 
ектов, субсидии, гранты; госзакупки с приоритетом экологических составляющих; снижение рисков посредством выпуска обеспеченных облигаций, секьюритизации ценных бумаг; 2) косвенные: формирование системы льгот (экологические налоги и сборы, субсидирование процентных ставок, гарантии, государственное страхование и др.).

К стимулирующим мерам относятся такие как: финансовые льготы и стимулы, организационная и информационная поддержка бирж, институтов развития; санкционные меры включают систему повышающих коэффициентов при расчете платы за НBOC, применяемых за несоблюдение экологических нормативов.

\section{Формирование «контура поддержки» рынка зеленого финансирования на основе принципов устойчивого развития}

В Российской Федерации последовательно реализуется комплекс мер, направленный на стимулирование внедрения зеленых технологий в экономику и развитие рынка зеленого финансирования. В ключевых стратегиях и нормативных документах, являющихся институциональной основой становления и дальнейшего развития рынка экофинансирования, декларированы принципы государственной политики в сфере экологии и стимулирования экопроектов. Так, в Климатической доктрине Российской Федерации отмечен принцип приоритета национальных интересов России при разработке мер по регулированию последствий климатических изменений. Это важно, поскольку для российской экономики, в силу ее специфики, «слепое» внедрение положений, вытекающих из международных соглашений по регулированию климатических изменений, может привести к потере конкурентоспособности стратегических отраслей.

Принцип учета взаимосвязи экологических и экономических показателей зафиксирован в Концепции долгосрочного социально-экономического развития Российской Федерации на период до 2020 г., где цель экологической политики государства определена как качественное улучшение экологических условий при одновременном обеспечении развития экономики и конкурентоспособности ее отраслей.
Принцип комплексного учета воздействия антропогенных факторов на все природные сферы реализуется в Национальном проекте «Экология», который направлен на улучшение показателей в сферах земли (ликвидация несанкционированных свалок, уменьшение производственных и непроизводственных отходов, сохранение лесов), воды (улучшение качества питьевой воды, восстановление экологических ландшафтов значимых водных объектов (в том числе реки Волга, озер Байкал и Телецкое)), воздуха (снижение загрязнения воздуха); на сохранение объектов живой и неживой природы (сохранение биоразнообразия); на стимулирование внедрения наилучших доступных технологий (далее - НДТ).

Принцип взвешенности в принятии решений по установлению нормативных требований в сфере экологической безопасности учитывается в Стратегии экономической безопасности Российской Федерации на период до 2030 г., в которой отмечается, что факторы, связанные с глобальным изменением климата, начинают оказывать существенное влияние на экономическую безопасность страны, что может проявиться в нехватке продовольственных ресурсов, питьевой воды, обострении конкурентной борьбы за природные ресурсы Арктики и Антарктики, территории Северного Ледовитого океана. В Стратегии указывается, что регулирование экономики должно носить продуманный характер и исключить избыточные требования в сфере экологической безопасности, поскольку это может нарушить устойчивость стратегических отраслей.

Принцип зависимости в современных условиях экономического развития от состояния экологии определен в Основах государственной политики в области экологического развития Российской Федерации на период до 2030 года. В документе подчеркивается, что экономическое развитие должно идти в рамках экологоориентированного роста экономики и не должно приводить к ухудшению экологической обстановки и окружающей среды.

Принцип ответственности за причинение вреда окружающей среде реализуется в системе платежей: плата за негативное воздействие на окружающую среду, утилизационный и экологические сборы. 
Конкретная система экономических, экологических и социальных показателей (ESGпоказателей) предлагается Минэкономразвития России в рамках разработки проекта публичной нефинансовой отчетности и ее показателей. Считаем, что они могут использоваться для расчета рейтинга инвестиционного потенциала экологических проектов, наряду с традиционными показателями экономической эффективности.

\section{Поддержка \\ «зеленых» финансовых инструментов в российской экономике}

Документы, рассмотренные выше и определяющие политику государства в различных природных сферах, а также декларирующие обязательность финансирования хозяйствующими субъектами негативных воздействий хозяйствующей деятельности на окружающую среду, являются основополагающими нормативными актами в системе формирования российской экофинансовой системы. Они составляют «институциональный каркас» рынка экоинвестирования и финансирования. Помимо этого, в Российской Федерации разработаны и активно внедряются финансовые меры, направленные на стимулирование и развитие «зеленого» финансового рынка.

Рынок «зеленых» инструментов финансирования в российской экономике только начинает развиваться. Первый выпуск «зеленых» облигаций в России состоялся 19 декабря 2018 г., их разместила на Московской бирже компания «Ресурсосбережение XMAO». Номинальная стоимость этих облигаций составляет 1,1 млрд руб., доходность размещения $9,76 \%$, купон облигаций привязан к инфляции и ключевой ставке Банка России [Впервые в России ..., 2019]. Средства от размещения облигаций планируется направить на создание полигона для переработки твердых коммунальных отходов в районах Севера России. В 2019 г. стал активно развиваться «зеленый» сектор на фондовых биржах. Были размещены первые выпуски «зеленых» облигаций как компаний реального сектора экономики, так и финансовых институтов. В настоящее время в Секторе устойчивого развития Московской биржи котируются облигации бан- ка «Центр-Инвест», компании АО «Коммерческая недвижимость ФПК "Гарант-Инвест"», компании ООО «СФО РуСол 1». Как «зеленые» верифицированы облигации Компании «Ресурсосбережение XMAO». О намерении выпустить «зеленые» финансовые инструменты заявили и другие российские компании: РЖД, АО «Коммерческая недвижимость ФПК “Гарант-Инвест”».

Создание сектора устойчивого развития Московской биржей явилось значимым событием для российского финансового рынка зеленого финансирования, поскольку позиционируется как площадка именно для «зеленых» облигаций. Но для привлечения финансирования экопроектов возможно использовать и другие секторы и площадки, такие как Сектор роста и Рынок инноваций и инвестиций Московской биржи. Данные секторы только начинают развиваться и привлекать инвесторов: на текущее время в секторе устойчивого развития размещены ценные бумаги трех эмитентов, в секторе роста - 31 эмитента, в секторе рынка инноваций и инвестиций - 15 эмитентов. Сравнительная характеристика площадок приведена в таблице.

К ключевым мерам поддержки, стимулирования и развития отечественного экофинансового рынка относятся следующие:

1. Направление средств федерального бюджета и бюджетов субъектов Российской Федерации на финансирование природоохранных проектов [Федеральный закон ..., ст. 17, 2002]. Государственная поддержка осуществляется при реализации проектов, имеющих экологическую направленность, благодаря внедрению которых снижается антропогенная нагрузка на окружающую среду, сохраняется экологическое равновесие и биоразнообразие. Это такие направления, как: внедрение наилучших доступных технологий, разработка и внедрение проектов, направленных на снижение вредных выбросов в атмосферный воздух, в водные объекты, снижение отходов производства, обеспечение полезного использования попутного нефтяного газа.

2. Субсидии на возмещение затрат, связанных с выплатой купонных доходов по финансовым инструментам, предназначенным для финансирования экологических проектов, которые предоставляются на возмещение зат- 


\section{Секторы экофинансирования Московской биржи}

\begin{tabular}{|c|c|c|c|}
\hline Сектор & Характеристика & $\begin{array}{c}\text { Меры стимулирования } \\
\text { и развития } \\
\end{array}$ & $\begin{array}{c}\text { Финансовые } \\
\text { инструменты }\end{array}$ \\
\hline $\begin{array}{l}\text { Сектор устойчи- } \\
\text { вого развития }\end{array}$ & $\begin{array}{l}\text { Сегменты: «зеленых» } \\
\text { облигаций, «социаль- } \\
\text { ных» облигаций и на- } \\
\text { циональных проектов. } \\
\text { Выпуск финансовых ин- } \\
\text { струментов должен со- } \\
\text { ответствовать Принци- } \\
\text { пам «зеленого» / соци- } \\
\text { ального финансирова- } \\
\text { ния, или целям и прин- } \\
\text { ципам Национальных } \\
\text { проектов, пройти проце- } \\
\text { дуру внешней оценки }\end{array}$ & $\begin{array}{l}\text { Меры господдержки: субсидии } \\
\text { из федерального бюджета россий- } \\
\text { ским компаниям на возмещение } \\
\text { затрат на выплату купонного до- } \\
\text { хода по облигациям, которые бы- } \\
\text { ли выпущены в рамках реализации } \\
\text { инвестиционных проектов по вне- } \\
\text { дрению наилучших доступных } \\
\text { технологий }\end{array}$ & $\begin{array}{l}\text { Облигации, } \\
\text { биржевые облигации }\end{array}$ \\
\hline Сектор роста & $\begin{array}{l}\text { Работа сектора направ- } \\
\text { лена на поддержку ком- } \\
\text { паний малой и средней } \\
\text { капитализации. Эмитен- } \\
\text { ты: компании, объемом } \\
\text { выручки не менее } \\
120 \text { млн руб. и не более } \\
10 \text { млрд (для эмитентов } \\
\text { облигаций) и } 25 \text { млрд } \\
\text { руб. (для эмитентов ак- } \\
\text { ций) }\end{array}$ & $\begin{array}{l}\text { Меры господдержки: компенса- } \\
\text { ции части затрат по выпуску ак- } \\
\text { ций и облигаций и выплате купон- } \\
\text { ного дохода по облигациям, раз- } \\
\text { мещенным на фондовой бирже. } \\
\text { Меры поддержки институтов } \\
\text { развития: поручительство / гаран- } \\
\text { тии от Корпорации МСП, участие } \\
\text { МСП банка в размещении ценных } \\
\text { бумаг. } \\
\text { Меры биржевой площадки: сни- } \\
\text { женные требования по free-float } \\
\text { (500 млн руб. вместо } 1 \text { млрд для } \\
\text { обыкновенных акций; } 250 \text { млн } \\
\text { руб. вместо } 500 \text { млн для привиле- } \\
\text { гированных акций) }\end{array}$ & $\begin{array}{l}\text { Облигации, облигации } \\
\text { без проспекта ценных } \\
\text { бумаг, биржевые об- } \\
\text { лигации, облигации по } \\
\text { секъюритизированным } \\
\text { кредитам), акции, паи } \\
\text { ЗПИФов }\end{array}$ \\
\hline $\begin{array}{l}\text { Рынок инноваций } \\
\text { и инвестиций }\end{array}$ & $\begin{array}{l}\text { Задачей сектора является } \\
\text { способствование росту } \\
\text { инвестиций в инноваци- } \\
\text { онные компании. } \\
\text { Эмитенты акций: компа- } \\
\text { нии с капитализацией не } \\
\text { менее } 500 \text { млн руб., эми- } \\
\text { тент соответствует }\end{array}$ & $\begin{array}{l}\text { Меры господдержки: налоговые } \\
\text { льготы для инвесторов по налогу на } \\
\text { прибыль и НДФЛ (исключение из } \\
\text { налогооблагаемой базы доходов от } \\
\text { реализации ценных бумаг россий- } \\
\text { ских эмитентов, включенных в пе- } \\
\text { речень ценных бумаг высо- } \\
\text { котехнологичного инновационного) } \\
\text { сектора экономики). } \\
\text { Меры подержки институтов } \\
\text { развития: рre-IPО финансирование, } \\
\text { льготное кредитование, доступ к } \\
\text { пенсионным накоплениям. } \\
\text { Меры биржевой площадки: РR и } \\
\text { IR-поддержка со стороны биржи }\end{array}$ & $\begin{array}{l}\text { Акции, облигации, } \\
\text { ADR, биржевые обли- } \\
\text { гации, ETF, паи акции, } \\
\text { паи ЗПИФов }\end{array}$ \\
\hline
\end{tabular}

Примечание. Составлено автором по: [Московская биржа].

рат по уплаченным процентам по кредитам и купонным доходам по облигациям по финансированию, полученному в 2014-2019 гг. для реализации комплексных инвестиционных проектов по приоритетным направлениям гражданской промышленности, к которым относятся и проекты создания экологически безопасных производств. Размер субсидий зависит от значений ключевой ставки Центрального банка Российской Федерации и кривой бескупонной доходности облигаций федерального займа со сроком погашения 10 лет с учетом корректирующих коэффициентов.

Также предоставляются субсидии по затратам на купонные доходы по облигациям, выпущенным для финансирования проектов наи- 
лучших доступных технологий. При этом общая стоимость выпуска облигаций должна составлять до 30 млрд рублей. Размер субсидии $-70 \%$ от суммы фактических затрат на выплату купона по облигациям, но не более 70 \% величины базового индикатора, определенного в соответствии с законодательством.

3. Меры поддержки финансовых институтов развития, такие как гарантии, поручительства, льготное кредитование.

Помимо поддержки, направленной на стимулирование и развитие финансового рынка, запланирована реализация следующих мер: модернизировать и перевести на принципы НДТ 300 российских предприятий, наносящих наибольший ущерб экологии России. Программа началась в 2019 г., срок ее реализации - до конца 2029 г., планируется, что до 2031 г. она охватит уже 7000 предприятий. Объем средств на программу -8 трлн рублей. Организации, внедряющие проекты НДТ, могут претендовать на следующие меры господдержки: льготы по оплате негативного воздействия на окружающую среду (далее - НBОC), инвестиционные льготные кредиты, льготные кредиты и займы на приобретение оборудования. Программа предусматривает выделение субсидий по процентным ставкам по инвестиционным кредитам, возмещение затрат на выплату купонного дохода по облигациям, налоговые льготы [применение специального коэффициента к норме амортизации (до 2)]. Объем средств на субсидии по проекту НДТ планируется на уровне 0,3 млрд руб. в 2019 г., 3 млрд руб. в 2020 г. и 6 млрд руб. - в 2021 г. [Кабмин утвердил ..., 2019]. Приведенные меры реализуются в рамках национального проекта «Экология».

По результатам исследования выделим следующие проблемы и перспективы развития экофинансовой системы в российской экономике:

Этап становления рынка «зеленых» финансовых инструментов. Рынок экофинансирования находится на начальной стадии своего развития не только в России (начало работы специализированной секции на Московской фондовой бирже - август 2019), но и в мире (12 лет рынку зеленых финансовых инструментов). Неясна динамика развития рынка, что делает сложным процесс прогно- зирования доходности и риска данных бумаг, возможна неправильная оценка их риска. С другой стороны, перспективы развития рынка хорошие, о чем говорит быстрый рост объемов рынка, присоединение к данному рынку как компаний и финансовых институтов, участие государственных институтов развития, оказываемые меры государственной поддержки, осознание важности экологических проектов для экономики страны и мира в целом всеми стейкхолдерами. В связи с этим отечественный фондовый рынок имеет хорошие перспективы развития зеленых финансовых инструментов и высокий потенциал развития сегмента зеленых финансов.

Повышенные затраты, связанные с выпуском «зеленых» финансовых инструментов. Для эмиссии зеленых облигаций необходимо прохождение процедуры соответствия Принципам зеленых облигаций, раскрытие информации, составление дополнительной отчетности, что увеличивает затраты эмитента. Возможным решением может являться развитие рынка экофинансирования, становление российских консалтинговых компаний, оказывающих услуги по верификации, консультированию эмитентов ценных бумаг, стандартизация процедур выхода подобных ценных бумаг на рынок, дальнейшее развитие нормативно-правовой базы для внедрения данных инструментов в российскую экономку в соответствии с международными стандартами.

\section{Санкционные меры за причинение вреда окружающей среде}

Отметим ключевой принцип, связанный с ответственностью бизнеса за негативное воздействие на окружающую среду: экономические субъекты обязаны компенсировать вред, нанесенный окружающей среде при ведении экономической деятельности. Данный принцип задекларирован в Федеральном законе № 7 «Об охране окружающей среды» [Федеральный закон ..., ст. 16.1, 2019]. В соответствии с ним государством применяются санкционные меры за превышение нормативов допустимых выбросов, нормативы допустимых сбросов, технологические нормативы в виде повышения платы за НВОС путем при- 
менения повышающих коэффициентов [Федеральный закон ..., ст. 16.5, 16.9, 2019].

В настоящее время существуют намерения Правительства Российской Федерации изменить систему платежей за негативное воздействие на окружающую среду и заменить ее экологическим налогом. Министерство финансов РФ разработало проект изменений в Налоговый кодекс РФ и планирует внести новую главу «Экологический налог» [Проект Федерального закона ... , 2018]. Министерство финансов РФ отмечает снижение сумм по экологическому сбору и платежей за негативное воздействие на окружающую среду и планирует существенный рост поступлений от экологического налога по сравнению с экологическими платежами, из которых в доход Федерального бюджета планируется направлять $5 \%$, в доход бюджета субъекта Российской Федерации - $95 \%$.

Аргументами «за» введение экологического налога являются следующие: необходимость обеспечивать финансирование деятельности Правительства Российской Федерации в сфере экологии для проведения экологической политики; низкая эффективность взимания неналоговых платежей, аргумент - снижение в динамике поступлений за негативное воздействие на окружающую среду; отсутствие должной мотивации у плательщиков экологических неналоговых платежей к правомерному поведению в форме платы за негативное воздействие на ок- ружающую среду, довод - «неуплата экологических неналоговых платежей не образует состава преступления, предусмотренного УК РФ»; замена экологических неналоговых платежей экологическим налогом позволит увеличить объем доходов бюджетов за счет лучшего администрирования налога посредством применения мер налоговой, административной и уголовной ответственности, механизмов принудительного и бесспорного взыскания [Проект Федерального закона ..., 2018].

В качестве альтернативной точки зрения приведем следующие доводы на основе анализа показателей, динамика которых представлена на рисунках 1-4. Динамика экологических правонарушений (рис. 1) показывает устойчивое снижение объема таких правонарушений $(-52,30 \%$ за 10 лет), что ставит под сомнение обоснование применения налогового администрирования;

За период с 2011 по 2018 г. наблюдается уменьшение объемов поступления экологических платежей с 4,43 млрд руб. в 2011 г. до 0,65 млрд руб. в 2018 г. (-85, 3 \%) (см. рис. 2), что с точки зрения наполняемости бюджета носит негативный характер. Однако отметим, что факторами снижения объемов платежей является снижение выбросов и загрязнений, стимулировать которое призван платеж, а также рост инвестиций на природоохранные мероприятия, затраты на которые уменьшают сумму экологических платежей (см. рис. 3; рис. 4).

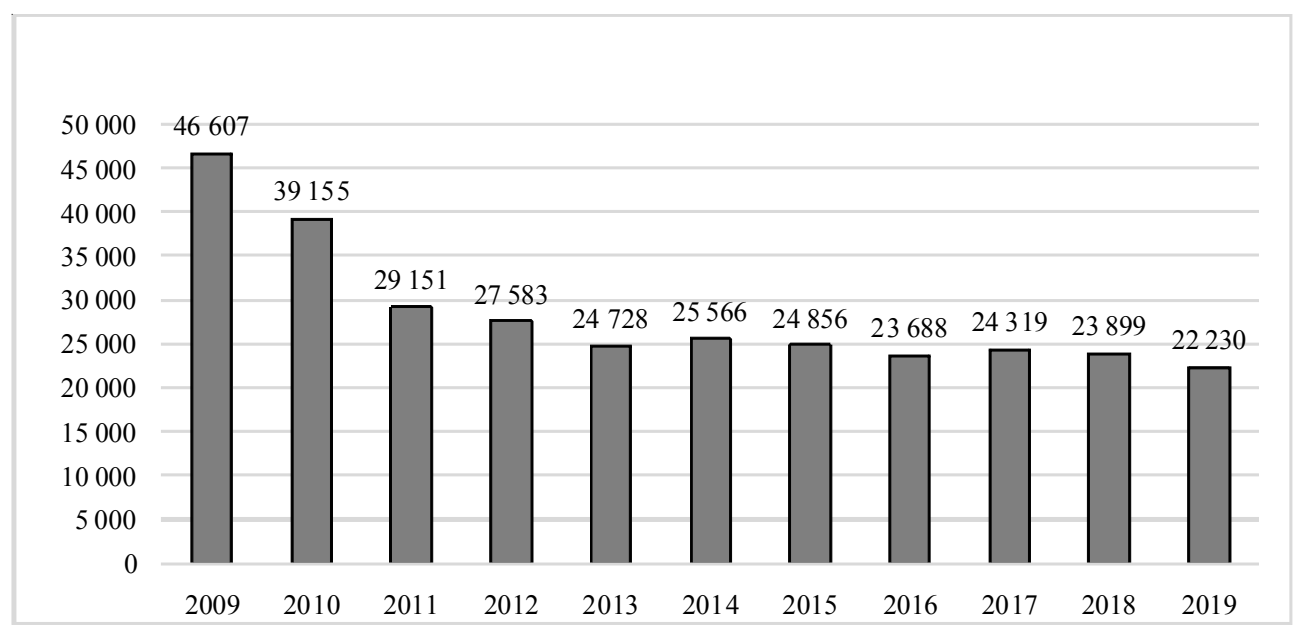

Рис. 1. Динамика экологических преступлений (2009-2019 гг.), количество

Примечание. Составлено автором по: [МВД РФ]. 


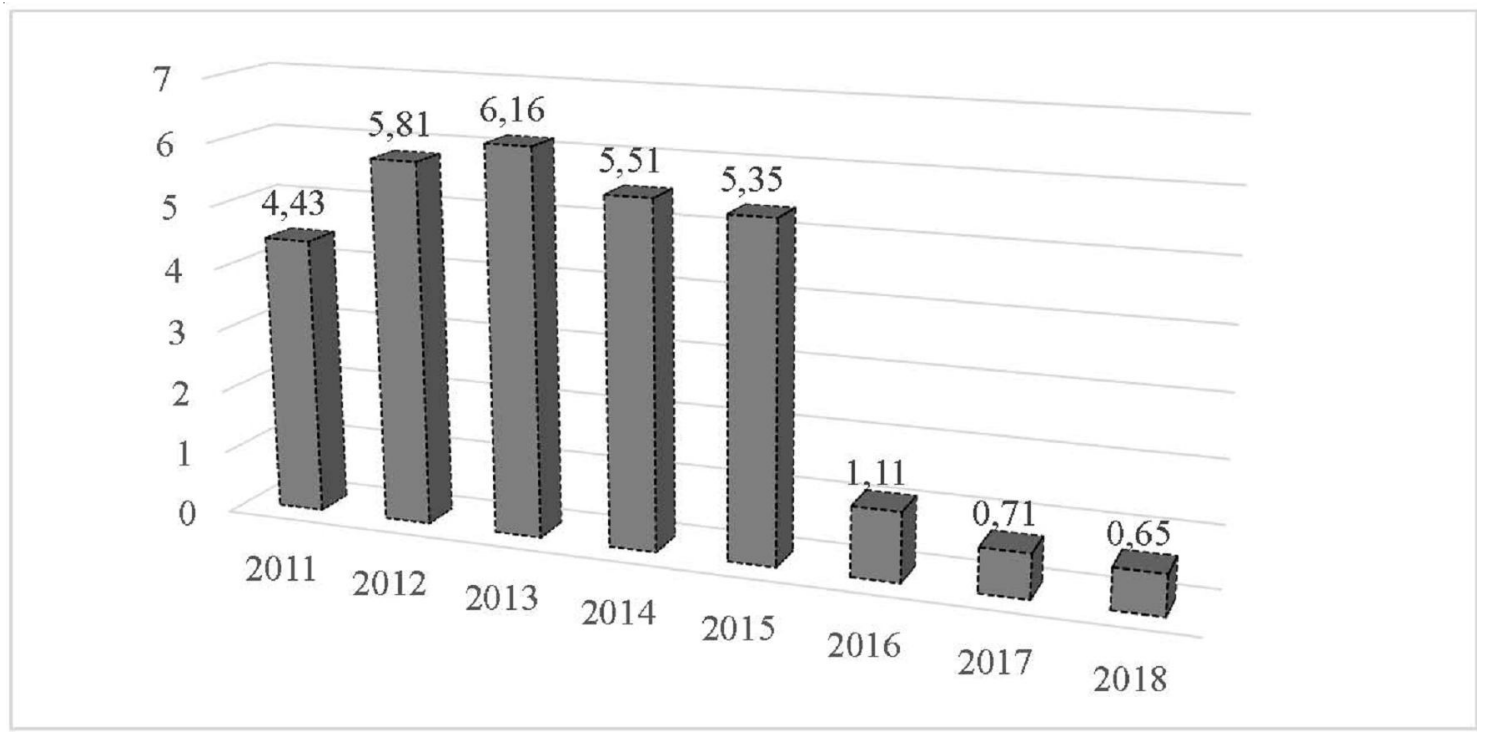

Рис. 2. Динамика платежей за негативное воздействие на окружающую среду (2009-2019 гг.), млрд руб. Примечание. Составлено авторами по: [Федеральное казначейство ...].

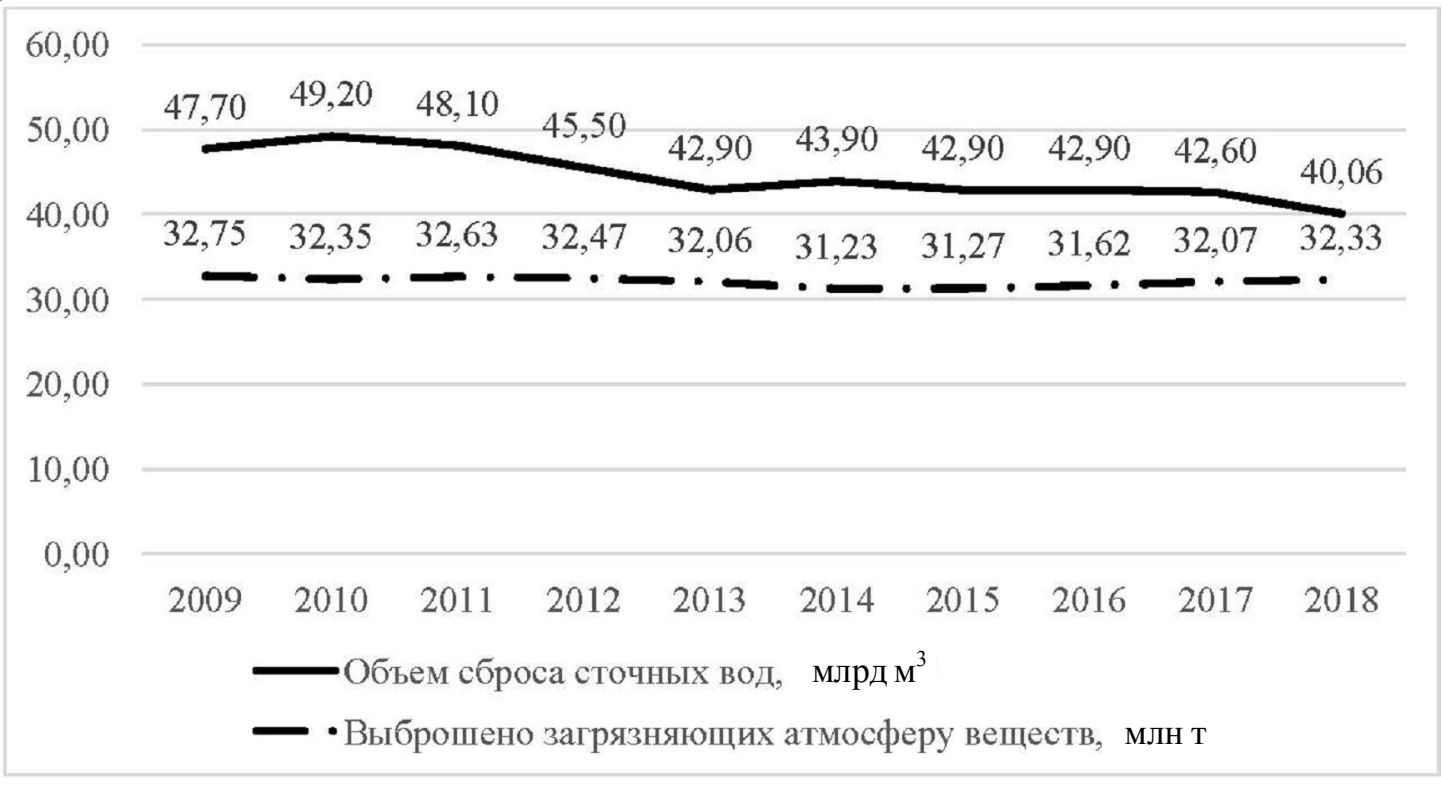

Рис. 3. Динамика объемов сброса сточных вод и выбросов загрязняющих веществ в атмосферу Примечание. Составлено авторами по: [Федеральная служба ...]. 


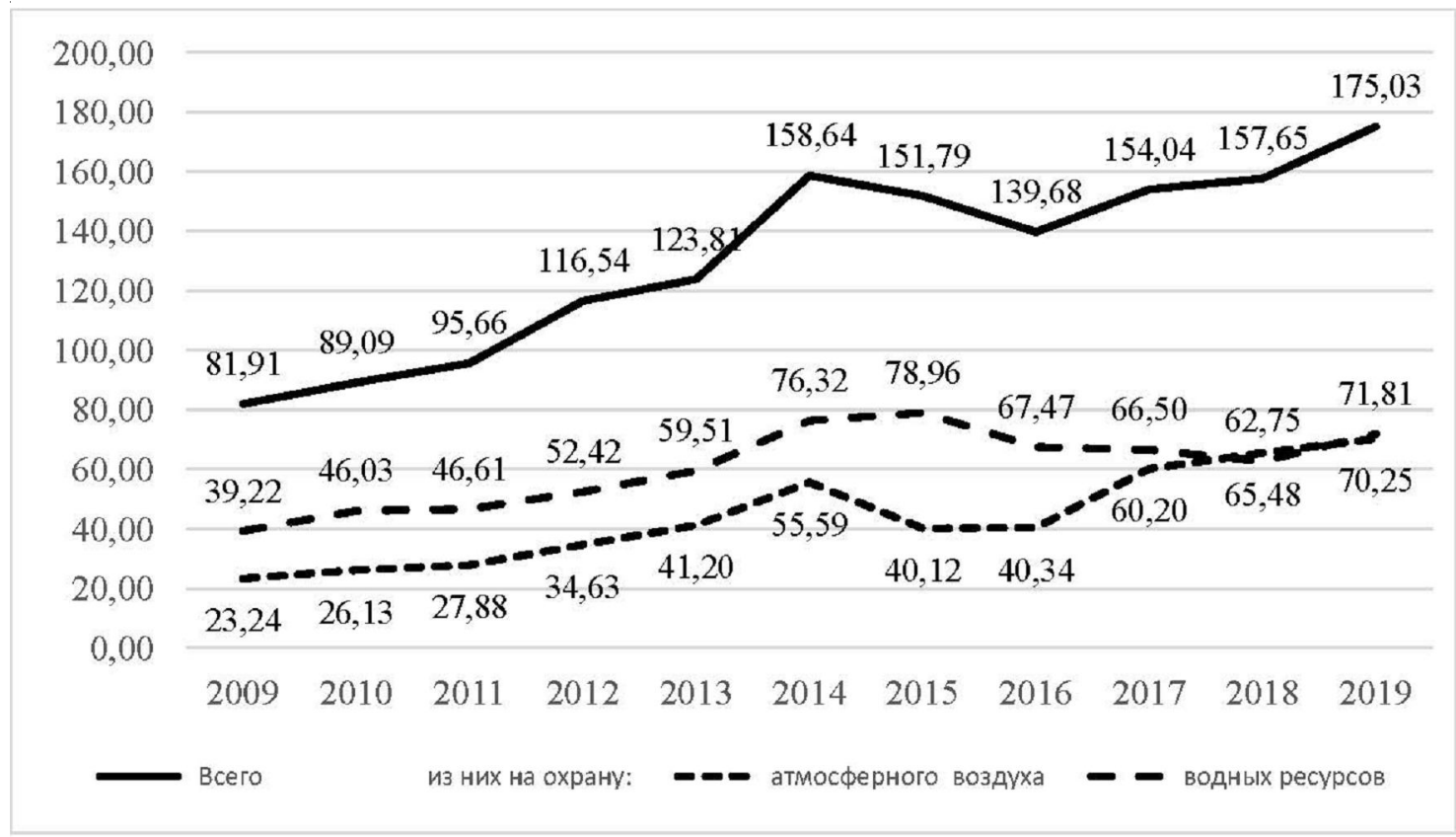

Рис. 4. Динамика инвестиций в основной капитал, направленных на охрану окружающей среды и рациональное использование природных ресурсов, в фактических ценах (млн руб.)

Примечание. Составлено авторами по: [Федеральная служба ...].

Природоохранные платежи должны использоваться на выполнение природоохранных мероприятий, в то время как налоговые платежи не носят целевого характера, следовательно при замене природоохранных платежей экологическим налогом снижаются стимулы для финансирования природоохранной деятельности. Отметим рост в динамике инвестиции на природоохранные мероприятия с 81,91 млн. руб. до 175,03 млн руб. за период с 2009 по 2019 г., что составило прирост $113,69 \%$ (см. рис. 4).

Снижение поступлений от природоохранных платежей объясняется реализацией организациями экологических проектов, направленных на уменьшение вредного воздействия на окружающую среду. Кроме того, расходы на природоохранные мероприятия снижают суммы природоохранных платежей. В проекте экологического налога сумма налога также может быть уменьшена на фактическую сумму расходов на природоохранные мероприятия, но не более, чем 70 \% начисленной суммы налога.

В настоящее время организация, внося плату за вредное воздействие на окружающую среду, уменьшает размер причиненного экологического ущерба и отказывается от требований полного возмещения затрат на покры- тие экологического ущерба. В случае перевода платежей за сбросы, выбросы загрязняющих веществ, захоронение отходов и другие виды вредного воздействия на окружающую среду в статус налогов, происходит переход к безвозмездным платежам (налог - это, по своей сути, безвозмездный платеж), что может привести к росту требований о полном покрытии экологического ущерба организациями без учета уплаченных сумм экологического налога. Это приведет к росту административной и финансовой нагрузки на бизнес и ухудшению условий его работы.

В финансово-экономическом обосновании проекта экологического налога отмечается, что принятие нового экологического налога не приведет к росту бюджетных расходов. Но налоговое администрирование предлагаемого налога требует усложнения процедуры по сравнению с действующей системой: так, предполагается введение в процедуры нового участника - Росприроднадзора, который будет подтверждать достоверность информации организаций об объемах негативного воздействия на окружающую среду, что увеличивает объем работы специалистов и может потребовать дополнительных затрат. 
Отметим и то, что меры стимулирования бизнеса к уменьшению вредных и загрязняющих выбросов в окружающую среду не дают качественного изменения существующей ситуации: так, с 2009 по 2018 г. объем сбора сточных вод в водные объекты уменьшился с 47,7 млрд куб. м до 40,06 млрд куб. м (на $14,77 \%$ ), загрязняющих веществ в атмосферу выброшено за аналогичный период меньше всего на 1,37 \% (32,75 млн т - в 2009 г. и 32,33 млн т - в 2018 г.) (см. рис. 1). Именно эти факты должны быть, по нашему мнению, основанием для совершенствования системы льгот и стимулов внедрения экологических производств и технологий.

Таким образом, в случае принятия экологического налога в предлагаемой редакции наблюдается противоречие между целями увеличения сумм налоговых платежей для роста доходов бюджетов и целями снижения объемов загрязнений окружающей среды, что снижает эффективность государственной политики в сфере природоохранной деятельности. Требуется тщательное обоснование перевода природоохранных платежей в экологический налог.

\section{Выводы}

Уточнена классификация мер государственной поддержки по классификационным признакам: по форме участия (прямая и косвенная поддержка), по видам поддержки (административные и финансовые), по направлениям поддержки (стимулирующие и санкционные) - и выделены применяемые меры поддержки в российской экономике. К административным мерам отнесены институциональные меры (формирование «институционального контура» поддержки рынка зеленого финансирования), организационные (организация научно-исследовательской работы по тематике зеленых финансов и экономики и разработка методических документов по классификации и оценке рисков). К мерам финансовой поддержки относятся прямые меры (выпуск государственных и муниципальных облигаций, субсидии, гранты, госзакупки и др.) и косвенные (экологические налоги и сборы, субсидирование процентных ставок, гарантии, государственное страхова- ние и др.). Среди стимулирующих мер преобладают налоговые льготы, дифференцированные ставки экологических сборов и платежей, субсидии, направленные на развитие «зеленых» финансовых инструментов; среди санкционных - издержки на компенсацию негативного вреда, нанесенного окружающей среде.

Анализ государственной поддержки экопроектов в российской экономике показал наличие мер как прямой, так и косвенной поддержки, направленной на стимулирование экологических проектов и снижение вреда окружающей среде от хозяйственной деятельности экономических субъектов, в частности: разработаны налоговые льготы для инвесторов, реализующих проекты природоохранной направленности; действует система экологических сборов и платежей за негативное воздействие на окружающую среду, стимулирующая уменьшение вредных выбросов; государством предлагаются меры по модернизации данной системы (внедрение экологического налога), которые находятся в настоящее время на стадии обсуждения; реализуются субсидии на возмещение затрат на выплату купонного дохода по облигациям, выпущенным в рамках реализации инвестиционных проектов по внедрению наилучших и доступных технологий; разработаны и реализуются меры поддержки эмитентов ценных бумаг, целевая направленность которых (ценных бумаг) связана с инвестированием в экопроекты, в инновационные проекты.

Таким образом, в российской экономике сложилась и действует система мер поддержки и стимулирования проектов в области зеленой экономики, дальнейшими направлениями модернизации которой должны стать: совершенствование системы налоговых платежей и сборов, оценка эффективности действующих мер.

\section{ПРИМЕЧАНИЕ}

${ }^{1}$ Исследование выполнено при финансовой поддержке РФФИ в рамках научного проекта № 19010-00356 «Совершенствование методологии оценки эколого-экономического развития регионов на основе концепции устойчивого развития».

The reported study was funded by RFBR according to the research project no. 19-010-00356 
"Improvement of the methodology for assessing the environmental and economic development of regions based on the concept of sustainable development".

\section{СПИСОК ЛИТЕРАТУРЫ}

Богачева, О. В. Государственные меры по организации и развитию рынка «зеленых» облигаций / О. В. Богачева, О. В. Смородинов // Финансовый журнал. - 2016. - № 3. - С. 55-65.

Впервые в России были размещены «зеленые» облигации // BSC Express. - Электрон. текстовые дан. - Режим доступа: https://bcsexpress.ru/novosti-i-analitika/vpervye-vrossii-byli-razmeshcheny-zelenye-obligatsii (дата обращения: 01.08.2019). - Загл. с экрана.

Гутборг, М. «Зеленые облигации» как новый финансовый инструмент и перспективы их внедрения в России / М. Гутборг, Ю. Храплива, С. Володин // Валютное регулирование. Валютный контроль. - 2017. - № 9. - С. 44-52.

Кабмин утвердил правила субсидирования "зеленых облигаций” 05.05.2019// ТАСС. - Электрон. текстовые дан. - Режим доступа: https:// tass.ru/nacionalnye-proekty/6404985 (дата обращения: 10.01.2020). - Загл. с экрана.

Каменева, Е. Финансовый инструментарий повышения энергоэффективности экономики России / Е. Каменева, Т. Седаш // Менеджмент и бизнес-администрирование. - 2015. - № 4. C. 93-102.

МВД России. - Электрон. текстовые дан. - Режим доступа: https://мвд.pф/Deljatelnost/statistics (дата обращения: 18.04.2020). - Загл. с экрана.

Московская биржа. - Электрон. текстовые дан. Режим доступа: https://www.moex.com (дата обращения: 02.04.2020). - Загл. с экрана.

Проект Федерального закона «О внесении изменений в части первую и вторую Налогового кодекса Российской Федерации», 2018. - Доступ из справ.-правовой системы «КонсультантПлюс».

Седаш, Т. Зарубежный опыт финансирования инфраструктурных и энергосберегающих проектов / Т. Седаш // Управленческие науки в современном мире. - 2017. - Т. 1. - С. 463-465.

Тютюкина, Е. Экологические облигации и депозиты как источник финансирования природоохранных мероприятий / Е. Тютюкина, Т. Седаш // Финансовая жизнь. - 2015. - № 3. C. 58-62.

Федеральная служба государственной статистики. Электрон. текстовые дан. - Режим доступа: https://www.gks.ru(дата обращения: 18.04.2020). Загл. с экрана.
Федеральное казначейство (Казначейство России). Электрон. текстовые дан. - Режим доступа: http://www.roskazna.ru/ispolnenie-byudzhetov/ konsolidirovannyj-byudzhet (дата обращения: 18.04.2020). - Загл. с экрана.

Федеральный закон от 10.01.2002 № 7-Ф3 (ред. от 27.12.2019) «Об охране окружающей среды». Доступ из справ.-правовой системы «КонсультантПлюс».

Филичева, Т. П. О переводе природоохранных платежей в статус экологического налога / Т. П. Филичева, И. Д. Горкина // Территория новых возможностей. Вестник Владивостоксого государственного университета экономики и сервиca. - 2018. - T. 10, № 4. - C. 49-57.

\section{REFERENCES}

Bogacheva O.V., Smorodinov O.V. Gosudarstvennye mery po organizatsii i razvitiyu rynka «zelenykh» obligatsiy [State Measure for the Organization and Development of the Green Bond Market]. Finansovyy zhurnal [Financial Magazine], 2016, no. 3, pp. 55-65.

Vpervye v Rossii byli razmeshcheny «zelenyie» obligatsii [For the First Time in Russia, "Green" Bonds Were Placed]. BSC Express. URL: https:// bcs-express.ru/novosti-i-analitika/vpervye-vrossii-byli-razmeshcheny-zelenye-obligatsii (accessed 1 August 2019).

Gutborg M., Hrapliva Yu., Volodin S. «Zelenyie obligatsii» kak novyy finansovyy instrument $\mathrm{i}$ perspektivy ikh vnedreniya v Rossii [Green Bonds as a New Financial Instrument and the Prospects of Their Implementation in Russia]. Valyutnoe regulirovanie. Valyutnyy control [Currency Regulation. Currency Control], 2017, no. 9 , pp. 44-52.

Kabmin utverdil pravila subsidirovaniya "zelenyih obligatsiy" 05.05.2019 [The Cabinet of Ministers Approved the Rules for Subsidizing Green Bonds on May 5, 2019]. TASS. URL: https:// tass.ru/nacionalnye-proekty/6404985 (accessed 10 January 2020).

Kameneva E., Sedash T. Finansovyy instrumentariy povysheniya energoeffektivnosti ekonomiki Rossii [Financial Tools for Improving Energy Efficiency of the Russian Economy]. Menedzhment $i$ biznesadministrirovanie [Management and Business Administration], 2015, no. 4, pp. 93-102.

MVD Rossii [Ministry of Internal Affairs of Russia]. URL: https://мвд.pф/Deljatelnost/statistics (accessed 18 April 2020).

Moskovskaya birzha [Moscow exchange]. URL: https://www.moex.com (accessed 2 April 2020). 
Proekt Federalnogo zakona «O vnesenii izmeneniy $v$ chasti pervuyu i vtoruyu Nalogovogo kodeksa Rossiyskoy Federatsii» [Draft Federal Law "Amendments to Parts One and Two of the Tax Code of the Russian Federation"], 2018. Access from Reference Legal System 'KonsultantPlyus'.

Sedash T. Zarubezhnyy opyt finansirovaniya infrastrukturnykh i energosberegayushchikh proektov [Foreign Experience in Financing Infrastructure and Energy-Saving Projects]. Upravlencheskie nauki v sovremennom mire [Management Sciences in the Modern World], 2017, vol. 1, pp. 463-465.

Tyutyukina E., Sedash T. Ekologicheskie obligatsii i depozity kak istochnik finansirovaniya prirodookhrannykh meropriyatiy [Environmental Bonds and Deposits as a Source of Financing of Environmental Measures]. Finansovaya zhizn [Financial Life], 2015, no. 3, pp. 58-62.

Federalnaya sluzhba gosudarstvennoy statistiki [Federal State Statistics Service]. URL: https:// www.gks.ru (accessed 18 April 2020).
Federalnoe kaznacheystvo (Kaznacheystvo Rossii) [Federal Treasury (Treasury of Russia)]. URL: http://www.roskazna.ru/ispolnenie-byudzhetov/ konsolidirovannyj-byudzhet/ (accessed 18 April 2020).

Federalnyy zakon ot 10.01.2002 № 7-FZ (red. ot 27.12.2019) «Ob okhrane okruzhayushchey sredy» [Federal Law of 10.01.2002 No. 7-FZ (ed. from 27.12.2019) “On Environmental Protection"]. Access from Reference Legal System 'KonsultantPlyus'.

Filicheva T.P., Gorkina I.D. O perevode prirodookhrannykh platezhey $\mathrm{v}$ status ekologicheskogo naloga [On the Transfer of Environmental Payments to the Status of Environmental Tax]. Territoriya novykh vozmozhnostey. Vestnik Vladivostoksogo gosudarstvennogo universiteta ekonomiki $i$ servisa [Territory of New Opportunities. Bulletin of the Vladivostok State University of Economics and Service], 2018, vol. 10, no. 4, pp. 49-57.

\section{Information About the Author}

Andrey A. Anikin, Postgraduate Student, Department of Applied Informatics and Mathematical Methods in Economics, Volgograd State University, Prosp. Universitetsky, 100, 400062 Volgograd, Russian Federation,Ea-191_812768@volsu.ru, https://orcid.org/0000-0002-6960-4158

\section{Информация об авторе}

Андрей Андреевич Аникин, аспирант кафедры прикладной информатики и математических методов в экономике, Волгоградский государственный университет, просп. Университетский, 100, 400062 г. Волгоград, Российская Федерация, Еa-191_812768@volsu.ru, https://orcid.org/0000-0002-6960-4158 